

\section{Daftar Isi (Table of Content) Journal of Government
Civil Society}

\begin{tabular}{|c|c|}
\hline \multirow{3}{*}{$145-158$} & $\begin{array}{l}\text { Political Law's Reconstruction of Village Apparatus to Realize Independent } \\
\text { Village in Indonesia }\end{array}$ \\
\hline & Hartati $^{1}$, Pahrudin HM$^{2}$, Elita Rahmi ${ }^{1}$ \\
\hline & $\begin{array}{l}\text { ('Faculty of Law, Universitas Jambi, Indonesia) } \\
\text { ('Departement of Government Science, STISIP Nurdin Hamzah Jambi, Indonesia) }\end{array}$ \\
\hline \multirow{3}{*}{$159-179$} & $\begin{array}{l}\text { Policy of a Merit System to Make a Good and Clean Government in The } \\
\text { Middle of Bureaucratic Politicization }\end{array}$ \\
\hline & $\begin{array}{l}\text { Yahya Pandega Putra1, 2, Eko Priyo Purnomo, 2, Suswanta Suswanta1, } \\
\text { Aulia Nur Kasiwi1, }\end{array}$ \\
\hline & $\begin{array}{l}\text { ('Jusuf Kalla School of Government, Universitas Muhammadiyah Yogyakarta, Indonesia) } \\
\text { ('Department of Government Affairs and Administration, Universitas Muhammadiyah } \\
\text { Yogyakarta, Indonesia) }\end{array}$ \\
\hline \multirow{3}{*}{$181-199$} & $\begin{array}{l}\text { Smart Human Security: Economic Safety for Micro, Small and Medium } \\
\text { Enterprises (MSMEs) to Face The Impact of The Covid-19 Global Pandemic }\end{array}$ \\
\hline & Elyta $^{1}$, Warjio ${ }^{2}$, Ahmad Azrin Bin Adnan ${ }^{3}$ \\
\hline & $\begin{array}{l}\text { ('Faculty of Social and Political Sciences, Universitas Tanjungpura, Indonesia) } \\
\text { ('Faculty of Social and Political Sciences, Universitas Sumatera Utara, Indonesia) } \\
\text { ('Faculty of Business and Management, Universiti Sultan Zainal Abidin (UnisZa), } \\
\text { Trengganu, Malaysia) }\end{array}$ \\
\hline \multirow{3}{*}{$201-218$} & $\begin{array}{l}\text { Using The "Return on Investment" Strategy to Sustain Logistic Supply } \\
\text { Provider Toward Indonesia's Logistic Policy }\end{array}$ \\
\hline & Riska Rahayu $\mathbf{u}^{1,2}$, Eko Priyo Purnomo ${ }^{1,2}$, Ajree Ducol Malawani,1,3 \\
\hline & $\begin{array}{l}\text { ('1usuf Kalla School of Government, Universitas Muhammadiyah Yogyakarta, Indonesia) } \\
\text { ('Magister of Government and Public Affairs, Universitas Muhammadiyah Yogyakarta, } \\
\text { Indonesia) } \\
\text { ('Doctoral Program of Political Islam, Universitas Muhammadiyah Yogyakarta, Indonesia) }\end{array}$ \\
\hline \multirow{3}{*}{$219-228$} & $\begin{array}{l}\text { Indonesia Universal Health Coverage Implementation on University } \\
\text { Students }\end{array}$ \\
\hline & Adityo Pratikno Ramadhan'1, Budiyono Budiyonoㄹ, Djonet Santoso' ${ }^{1}$ \\
\hline & ('Sustainable Development Goals Center, Universitas Bengkulu, Indonesia) \\
\hline
\end{tabular}


The Local Government of Kulon Progo Regency Innovation in Subduing Capitalism through Community Empowerment

229 - 247 Muhammad Eko Atmojo ${ }^{1}$, Helen Dian Fridayani ${ }^{2}$

('Departement of Government Science, Universitas Muhammadiyah Yogyakarta, Indonesia)

('Departement of Political Science, National Cheng Kung University, Taiwan)

Land Administration Policy In Bantul and Sleman Districts

$249-272$

Subekti Widiyasno1, Dyah Mutiarin 1, Herdin Arie Saputra1, Ikhwan

Rahmatika Latif ${ }^{1}$

('Department of Government Affairs and Administration, Universitas Muhammadiyah Yogyakarta, Indonesia)

Increasing Local Own-Source Revenue through The Development of The Regional Tourism Sector

$273-291$

Harries Madiistriyatno', Ida Musdafia Ibrahim², Dudung Hadiwijaya ${ }^{3}$

('Program Studi Magister Manajemen Sekolah Tinggi Manajemen IMMI, Indonesia) (2Program Studi Manajemen Sekolah Tinggi Ilmu Ekonomi Y.A.I, Indonesia)

(3Program Studi Manajemen, Universitas Muhammadiyah Tangerang, Indonesia) 


\title{
Land Administration Policy In Bantul and Sleman Districts
}

\author{
Subekti Widiyasno ${ }^{1 *}$, Dyah Mutiarin ${ }^{1}$, Herdin Arie Saputra ${ }^{1}$, \\ Ikhwan Rahmatika Latif ${ }^{1}$ \\ ${ }^{1}$ Department of Government Affairs and Administration, Muhammadiyah University of Yogyakarta, \\ Indonesia \\ *Email Correspondence: mutiarin@yahoo.com
}

\begin{abstract}
The collection of land belonging to the Yogyakarta Palace or Sultan Ground (SG) and the Paku Alaman Duchy or Paku Alam Ground (PAG) land has been slow due to overlapping regulations. The collection of Sultan Ground and Paku Alam Ground land which is regulated in the Privileges Act is hampered by changes in the status of land ownership at the village level which belongs to the state and individuals. The certification process by the National Land Agency cannot be carried out yet. This data collection is based on Special Region Regulation No. 1 of 2017 concerning Management and Utilization of Sultanate Land and Duchy Land. The purpose of this study was to analyze land management policies in sustainable areas in the regencies (four) villages in Bantul Regency and Sleman Regency. This type of research conducted by the author is a mixed/mixed research (mixed methodology). Data analysis techniques in this study used the Nvivo 12 Plus software, processing by using the Crosstab Query Analysis, Cluster Analysis, Comparasis Diagram Analysis features. The results of research in land management are still not carried out correctly and evenly. Several problems were encountered, such as the absence of road access, missing land boundaries, land parcels occupying other community lands, and conflicts.
\end{abstract}

Keywords: Policy, land arrangement, development, sustainable areas

\begin{abstract}
ABSTRAK
Pendataan tanah milik Keraton Yogyakarta atau Sultan Ground (SG) dan tanah Kadipaten Paku Alaman atau Paku Alam Ground (PAG) berjalan lambat karena terkendala aturan yang tumpang tindih. Pendataan tanah Sultan Ground dan Paku Alam Ground yang diatur dalam Undang-Undang Keistimewaan terganjal oleh perubahan status kepemilikan tanah di tingkat desa yang menjadi milik negara dan perorangan. Akibatnya proses sertifikasi oleh Badan Pertanahan Nasional belum bisa dilakukan. Pendataan ini dilandasi Peraturan Daerah Istimewa No 1 Tahun 2017 tentang Pengelolaan dan Pemanfaatan Tanah Kasultanan dan Tanah Kadipaten. Tujuan penelitian ini untuk menganalisis kebijakan penataan pertanahan di kawasan berkesinambungan di 4 (empat) desa di Kabupaten Bantul dan Kabupaten Sleman. Jenis penelitian yang dilakukan oleh penulis adalah penelitian campuran/ kombinasi (mixed methodology). Teknik analisis data dalam penelitian ini menggunakan software Nvivo 12 Plus, mengolah dengan menggunkan fitur Crosstab Query Analysis, Cluster Analysis, Comparasison Diagram Analysis. Hasil penelitian dalam penataan pertanahan masih belum dilakukan secara baik dan merata, terdapat beberapa permasalahan yang dijumpai seperti tidak adanya akses jalan, batas tanah yang hilang, bidang tanah menempati wilayah tanah masyarakat yang lain, dan konflik.
\end{abstract}

Kata Kunci: Kebijakan, penataan tanah, pembangunan, kawasan berkesinambungan

Citation : Widiyasno, Subekti, Dyah Mutiarin, Herdin Arie Saputra, Ikhwan Rahmatika Latif. 2020. "Land Administration Policy In Bantul and Sleman Districts." Journal of Government and Civil Society $4(2): 249-272$. 


\section{INTRODUCTION}

The development of residential areas at this time does not pay attention to the total land area (Arnowo \& Handayani, 2016). This has made land-related problems more complex (Chayani \& Yuliani, 2013); (Marsella, 2015). Therefore, it is necessary to have an integrated land management policy between the National Land Agency and the community. It is suspected that adequate infrastructure improvements have not matched the high development of residential areas (Pinuji, 2016; Nugroho, 2015). In this case, a land management policy needs to be proposed with long-term interests, namely, sustainable/sustainable area development. The use of land needs to be managed optimally by the 1945 Constitution Article 33 paragraph (3) which reads: "The land, water and natural resources contained therein are controlled by the state and used as much as possible for prosperity of the people ". Currently, there are efforts to restore land policies that are based on equilibrium by the UUPA, through land management.

Studies show that corruption and abuse of power challenge the security of land ownership, adversely affecting the confidence of the private sector in securing property rights, leading to underutilization of land. Therefore, good governance in the land administration system is essential to promote economic development and ensure sound management through all levels of society (Blake, 2015). Land administration policies will also be successful if the services provided under the system are appropriate, accessible, predictable and reliable (Hilhorst, 2008). The implementation of the Land Use Law does not have a significant effect on land administration policies. The bureaucracy and weak institutional framework for administration have created governance problems (Kuma, 2018). The problem of land administration arrangement in DIY is related to the low ownership of community land certificates.

Land arrangement in the Special Region of Yogyakarta. Data collection on the lands belonging to the Yogyakarta Palace or Sultan Ground (SG) and the lands of the Paku Alaman or Paku Alam Ground (PAG) Kadipaten has been slow due to constraints. Changes hamper data collection of the Sultan Ground and Paku Alam Ground lands regulated in the UUK in land ownership status at the village level which belongs to the state and individuals. As a result, the certification process by BPN cannot be carried out (Puri, 2013). The land administration structuring policy is a priority program of the JokowiJK administration, especially reform of the bureaucracy in the land sector. This research complements previous studies conducted by other researchers related to bureaucratic reform in the land sector. This research is also by the National Research Master Plan.

\section{METHODS}

The type of research conducted by the author is a mixed methodology. Mixed Methods Research is a research design based on philosophical assumptions as well as the method 
of inquiry. Mixed research methods are also referred to as a methodology that provides philosophical assumptions in showing directions or giving instructions on how to collect data and analyze data as well as a combination of quantitative and qualitative approaches through several phases of the research process (Sugiyono, 2018). This study uses a sequential mix method, especially a sequential explanatory strategy, which is to collect and analyze quantitative data followed by collection and analysis that is built on initial qualitative results. The mix of methods is combined to obtain more comprehensive, practical, reliable and objective data together in research activities.

The data analysis technique in this study uses the Nvivo 12 Plus software, processing it using the Crosstab Query Analysis, Cluster Analysis, Comparison Diagram Analysis features. The analysis was carried out in several stages, first, collecting secondary data and primary research data; the second stage is analysis with Nvivo 12 Plus software to read the text, information that has similarities with other data, find related items, look for interrelated meanings, words and contexts; the third stage is the meaning of the information that has been analyzed. The purpose of this study was to analyze land-use policies in sustainable areas in 4 (four) villages in Bantul and Sleman districts. Another objective is to determine the institutional factors of land management policies in Bantul and Sleman districts.

The paradigm shift of public administration places the government as an institution in carrying out a more oriented role towards public service (public service) or what is known as public administration. The shift in the service paradigm requires the government to act as the agent that regulates necessary public service affairs (Grover et al., 2007).

The concept of land policy is the process of determining, recording and disseminating information on tenure, value and use of land when implementing land management policies. "Thus, it can support sustainable development through the implementation of land policies and land management strategies (Blake, 2015). As defined by (Davison \& Osuch, 2009); (Augustinus, 2010); (Agnieszka Dawidowicz \& • róbek, 2017), the four functions of land policy are:

1. Land ownership

The process of allocating and securing land; cadastral mapping and determining the boundaries of parcels; transfer of property or use from one party to another through sale, lease or credit; security; ownership disputes and disputes over land rights and boundaries.

2. Land appraisal

Process related to land value appraisal; calculation and collection of income through taxation; adjudication of land appraisal and tax disputes. 
3. Land use

Control of land use through the adoption of planning policies and land use regulations at the national, regional and local levels.

4. Land development

The processes and institutions related to the construction of infrastructure and new physical utilities include the implementation of construction planning, land-use change through the granting of construction permits and building land use permits.

Good governance in land policy can lead to appropriate, effective and efficient land policies and strengthen the protection of property rights of individuals and companies (A. Dawidowicz et al., 2014); (Byd $\left.{ }^{3} \mathrm{Osz}, 2015\right)$. However, the state may be influenced by certain groups who unfairly use power (Manzhynski et al., 2016); (Maynard \& Jacobson, 2017).

To measure land administration policies according to (Manzhynski et al., 2016) there are three types, namely:

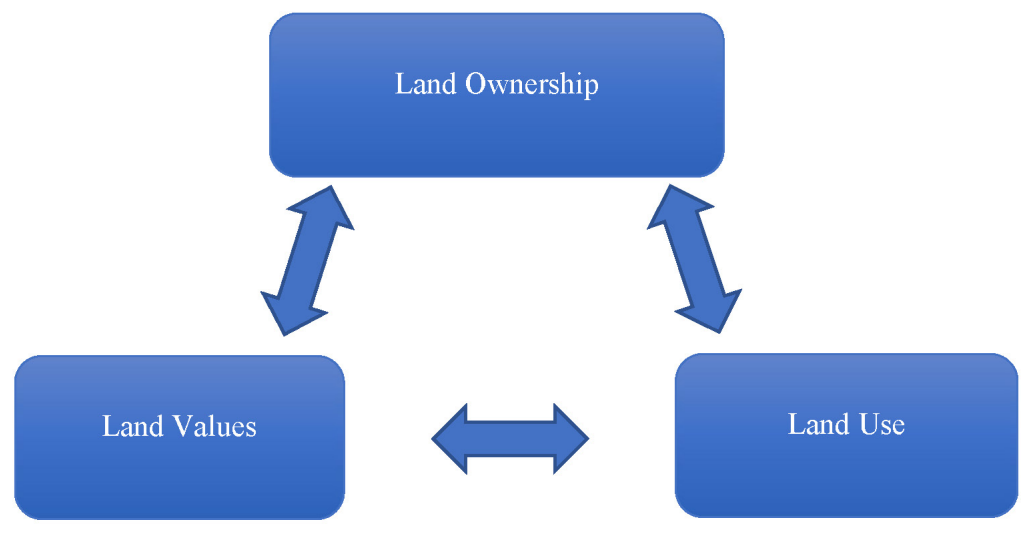

Figure 1. Land Administration Policy

Land administration policy can also be undermined through the insufficient capacity to carry out its main functions and functions effectively (Alemie et al., 2015).

1. Legal or regulatory challenges

Weak governance reduces tenure security and opens the door to illegal transfers, which result in owners losing their land titles. This ownership is not protected by law. It can even lead to land disputes. In some cases, courts may provide healthy, supportive decisions, independent of the benefits of marginalized groups. State-owned land can also be transferred to powerful men without adequate payments (Grover et al., 2007). 
2. Institutional challenges

Sometimes the leaders used their political power or undue advantage of the system to increase their land ownership. In such a case, promoting a sound land administration system policy may be a challenge at the local level (Hilhorst 2008). Also, ineffective land dispute resolution systems, weak institutional capacity and land administration processes, or indifference between land administration authorities and users can present institutional challenges to good governance in land administration (Blake, 2015).

3. Capacity constraints

Involving local governments in land administration in the form of land use planning and promoting sustainable use of natural resources and environmental management will expand opportunities for local government agencies to implement their mandates and build their capacity. But sometimes the capacity of local governments to operate depends on legal feasibility and sufficient resources to carry out their duties and responsibilities (Hilhorst, 2008); (Zevenbergen et al., 2016). Also, lack of resources to ensure good governance, lack of qualified or competent staff, lack of institutional capacity to manage land, and mismanagement of resources are other challenges that reduce the capacity for effective land administration, especially at the local government level (Grover et al., 2007).

Good governance in society can only be achieved through well-managed processes. Such processes also mean that government is well-managed and inclusive and produces the desired results (Van Doeveren, 2011); (Boone, 2015), also one of them is good governance in land policy (Good Land Governance).

According to (Grover et al., 2007); (Zevenbergen et al., 2016), Good Land Governance involves a more participatory and transparent process and aims to protect the property rights of individuals and companies based on a set of generally accepted principles. These principles can be implemented through fairness, efficiency, transparency and accountability, public participation and security.

A significant land administration system policy should also include capacity building, institutional development, and social interaction and focus on users and not just land administration service providers.

\section{RESULT AND DISCUSSION}

Tirtomulyo Village Land Planning Policy Kretek District and Gadingsari Village Sanden District Bantul Regency

In general, land management uses a land-use management pattern that includes control, use, and land use. The basic principle in land management is to achieve optimal 
benefits by considering land suitability, spatial allocation and sustainability. Meanwhile, the purpose of land management is to make the land a natural resource that can be utilized by the community in a sustainable, optimal, harmonious and balanced manner (Arnowo \& Handayani, 2016).

1. Land Ownership in Tirtomulyo Village, Kretek District and Gadingsari Village, Sanden District, Bantul Regency

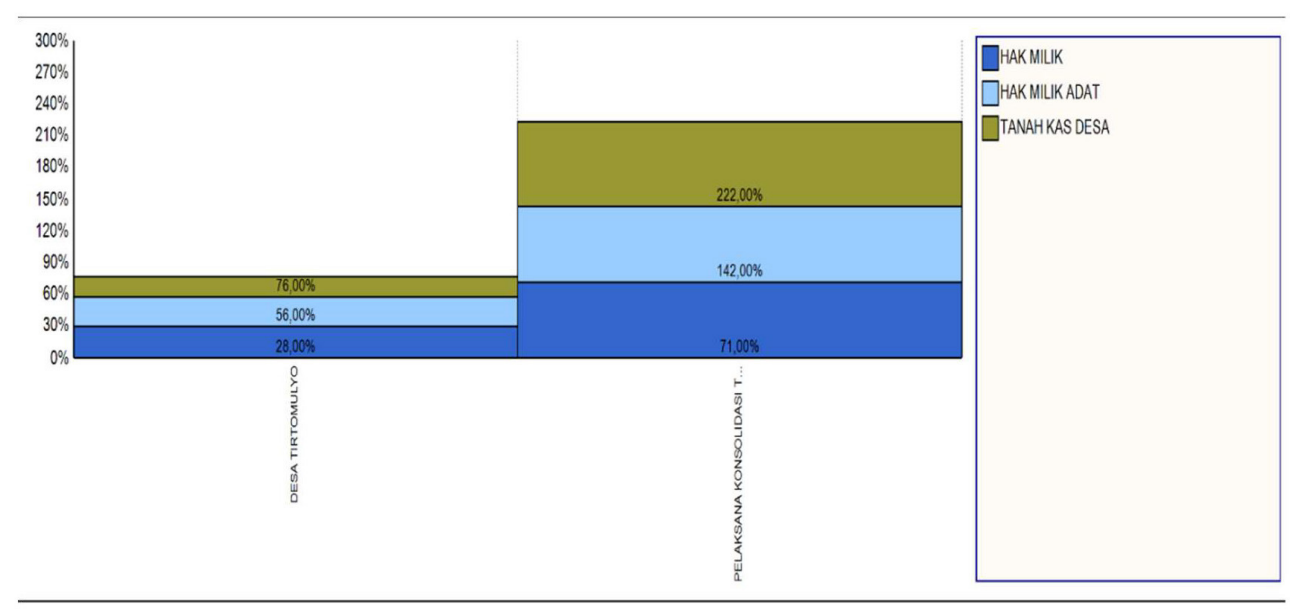

Figure 2. Land Ownership in Tirtomulyo Village Source: Processed by the author

Based on Figure 2. The crosstab analysis above shows that land ownership in Tirtomulyo Village, Kretek District, Bantul Regency, such as freehold rights with the number of frequencies obtained by the Village Head and the Head of the Village Government Section, namely 28\%, then the Customary Ownership Rights with the number of frequencies obtained of $28 \%$, and followed by Village Treasury Land with the amount of $20 \%$. Meanwhile, according to the Implementer of Land Consolidation at the Regional Office of the National Land Agency for the Special Region of Yogyakarta with an indicator of Ownership Rights of $71 \%$, Adat Ownership Rights of 71\%, and Village Treasury Land of $80 \%$.

Of the two hamlets in Tirtomulyo Village with land tenure status, there are three types of indicators, namely Freehold, Customary Ownership and Village Treasury Land. The area of Tluren Hamlet is approximately 27 hectares, consisting of yards (approximately 15 hectares) and rice fields (approximately 12 hectares). Kas Desa land is approximately 43 hectares in the form of rice fields. The status of land ownership in Tokolan Hamlet consists of 2 types, namely Freehold and Customary Ownership Rights. The area of Tokolan Hamlet is approximately $16 \mathrm{Ha}$ which consists of Yard (approximately $7.4 \mathrm{Ha}$ ) and Rice Field (approximately $8.8 \mathrm{Ha}$ ). 


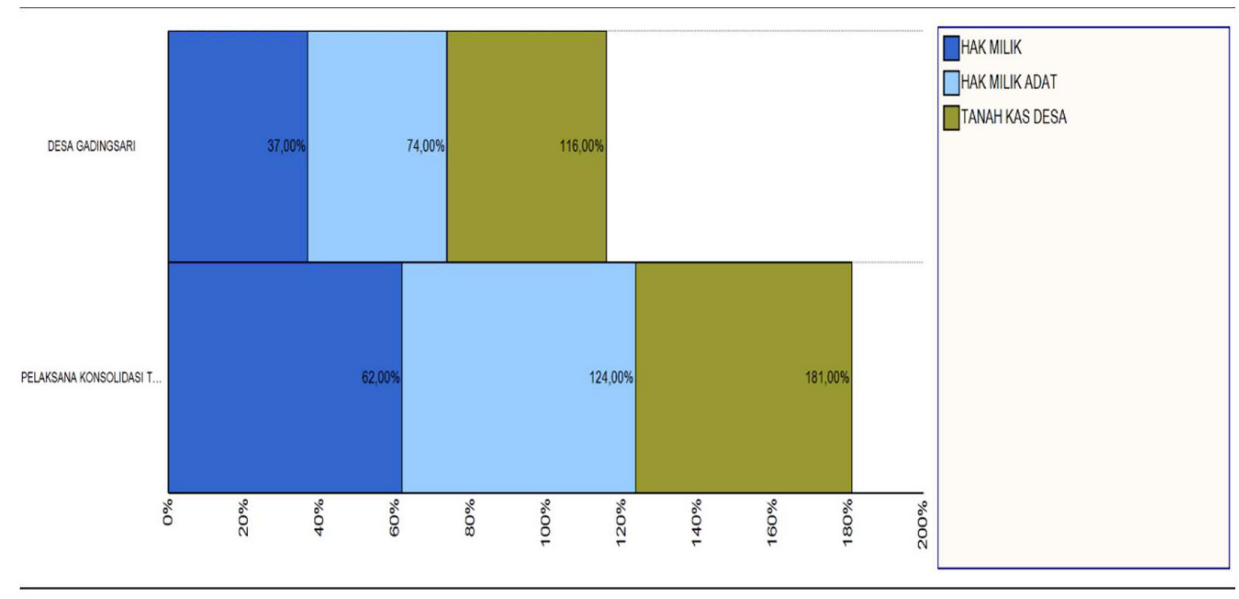

Figure 3. Land Ownership in Gadingsari Village

Source: Processed by the author

Figure 3. The crosstab analysis above shows that land ownership in Gadingsari Village, Sanden District, Bantul Regency. Land ownership is based on Hak Milik with a frequency of $37 \%$, customary rights with $37 \%$, and followed by Tanah Kas Desa with $42 \%$. The frequency with a total of $116 \%$ was based on what was said by the Head of Gadingsari Village and the Head of the Gadingsari Village Government Section. And while the total frequency of Implementers of Land Consolidation at BPN DIY Regional Office was 181\%. With each indicator, namely Freehold Rights with the amount of $62 \%$, followed by Adat Ownership Rights at $62 \%$, and Village Treasury Land with the amount of $57 \%$.

Of the three hamlets in Gadingsari Village with land tenure status, there are three types of indicators, namely Freehold, Adat Property and Village Treasury Land. Land tenure status in Bongos I Hamlet consists of 3 types, namely Freehold, Customary Ownership and Village Treasury Land. The land area that has been certified is approximately $21 \mathrm{Ha}(66.90 \%)$. Land tenure status in Dusun Demakan consists of 3 types, namely Freehold, Customary Ownership, and Village Treasury Land. The land area that has been certified is approximately $17 \mathrm{Ha}(70.83 \%)$. Land Tenure Status in Nanggulan Hamlet consists of 3 types, namely Freehold, Customary Ownership, and Village Treasury Land. In Nanggulan Hamlet, there are approximately 339 fields, of which 226 have been certified $(66.67 \%)$. 
2. Use of Land in Tirtomulyo Village, Kretek District and Gadingsari Village, Sanden District, Bantul Regency

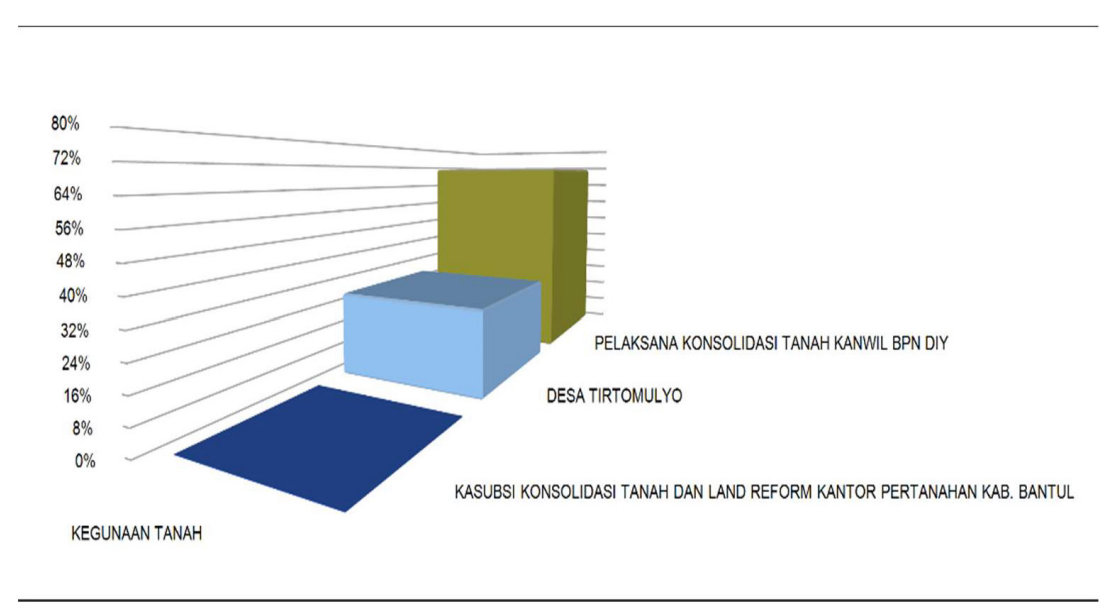

Figure 4. Use of Land in Tirtomulyo Village Source: Processed by the author

Figure 4. Above shows that the land use in the area of Tirtomulyo Village is $28 \%$ based on the Village Government. Meanwhile, according to the Implementer of Land Consolidation, the Regional Office of the National Land Agency for the Special Region of Yogyakarta was $71 \%$.

Land use in Tluren Hamlet is dominated by rice fields with an area of approximately 11.9 hectares $(44.11 \%)$, followed by residential areas covering approximately 8.08 hectares $(29.93 \%)$. And land-use in Tokolan Hamlet is dominated by rice fields covering an area of approximately 8.8 hectares $(54.27 \%)$. The area of the settlement (built area) is 29.93 hectares of $25.26 \%$.

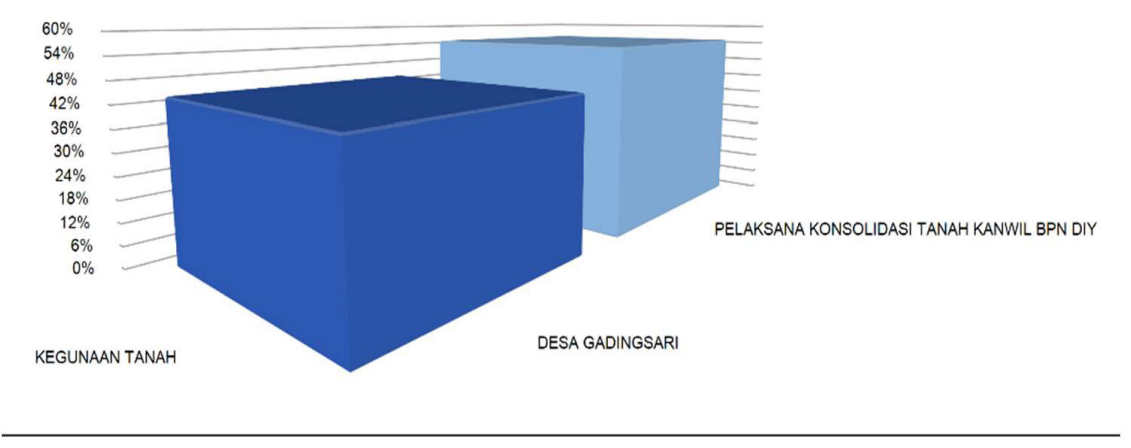

Figure 5. Use of Land in Gadingsari Village Source: Processed by the author 
Based on Figure 5. The crosstab above shows that the use of land in the Gadingsari Village area is $44 \%$ based on the Head of Gadingsari Village and the Head of the Gadingsari Village Government Section. Meanwhile, according to the Implementer of Land Consolidation, the Regional Office of the National Land Agency for the Special Region of Yogyakarta was 55\%.

Land use in Bongos I Hamlet is dominated by mixed gardens (77.41\%) even though the status of the land is Yard. The area of Bongos I Hamlet is approximately $31.39 \mathrm{Ha}$ consisting of Pekarangan (approximately 17.06 Ha) and Rice Field (approximately 14, 33 Ha). Land use in Dusun Demakan is dominated by mixed gardens (73.36\%) even though the status of the land is Yard. Dusun Demakan is approximately 24 hectares, consisting of yards (approximately 17 hectares) and rice fields (approximately 7 hectares). Land use in Nanggulan Hamlet is dominated by mixed gardens (76.06\%) even though the status of the land is Yard.

Problems in Land Management in Tirtomulyo Village, Kretek District and Gadingsari Village, Sanden District, Bantul Regency

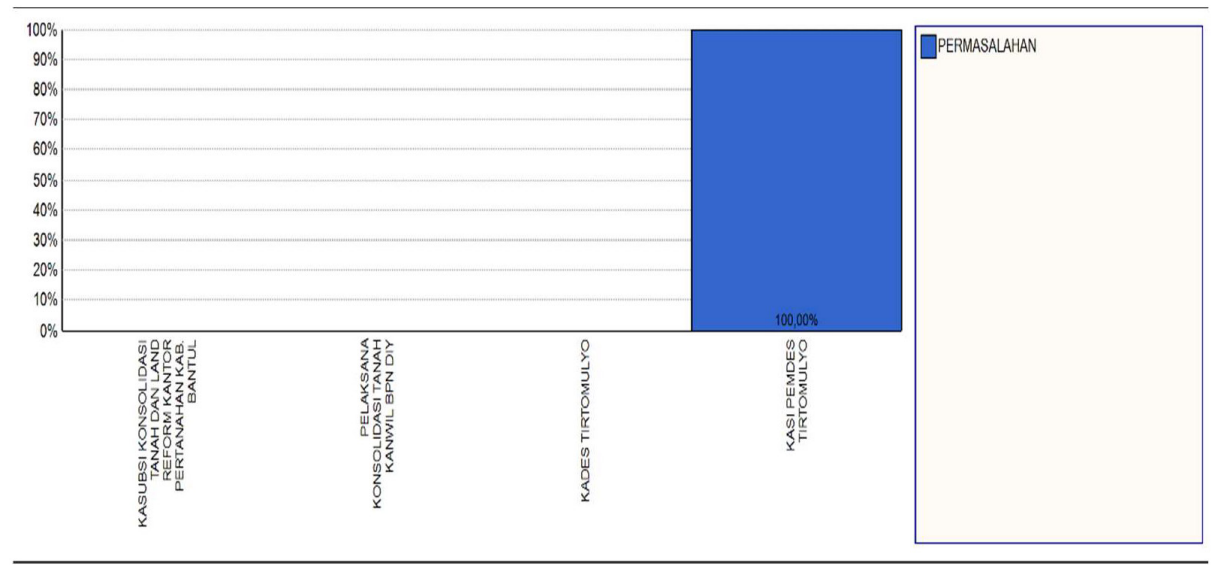

Figure 6. Problems in Land Management in Tirtomulyo Village Source: Processed by the author

Based on Figure 6. The crosstab analysis above shows that there are problems in land management in Tirtomulyo Village. The results above provide directions to problems, such as: First, there are many plots of land that do not have road access. Second, many access roads are relief roads (the area of roads that still occupy the land owned by residents. Third, the existing road access is not sufficiently narrow and is in the form of a dirt road with no road paving. 


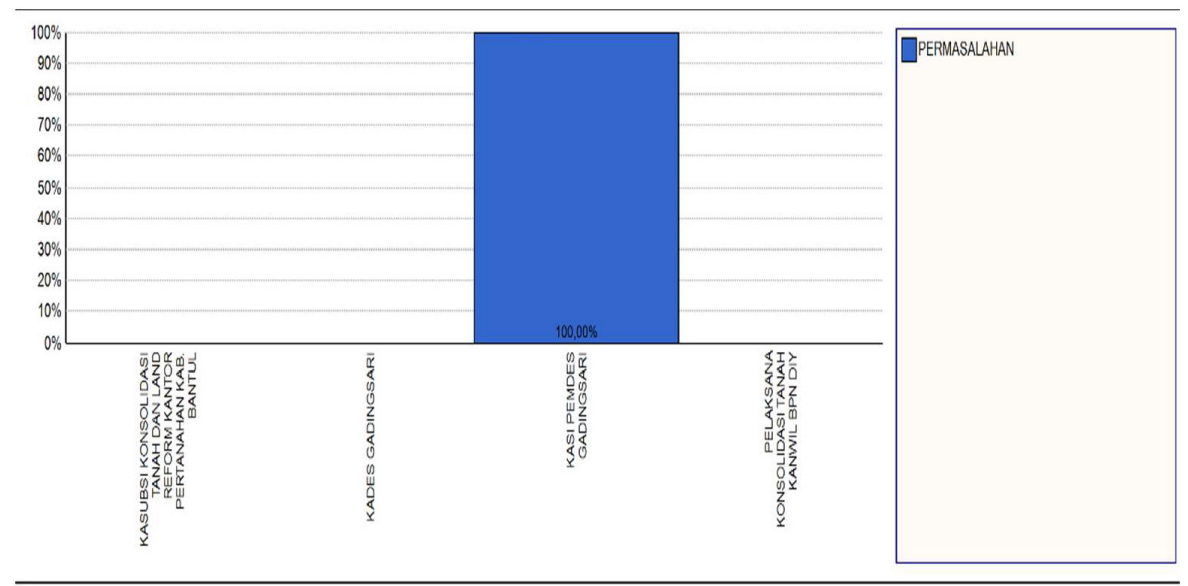

Figure 7. Problems in Land Management in Gadingsari Village Source: Processed by the author

Figure 7. Above shows that there are problems in land management in Gadingsari Village, Sanden District, Bantul Regency. The Head said this of the Gadingsari Village Government Section at $100 \%$. In these problems, namely, First, many land parcels do not have road access, there is inadequate road access so that four-wheeled vehicles cannot pass the road. Second, many roads that have not been removed from the ownership area have the potential for land conflicts and hamper economic growth in those locations.

The desire of the people of Tirtomulyo Village, Kretek District and Gadingsari Village, Sanden District, Bantul Regency

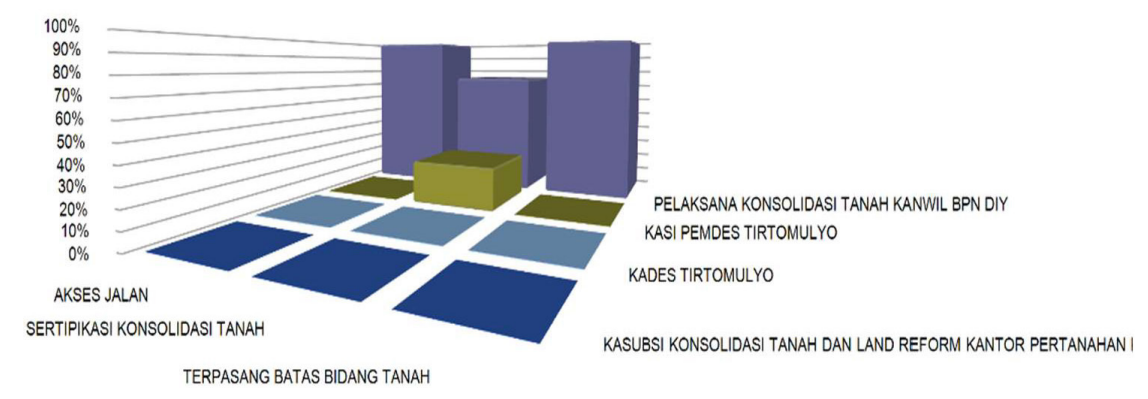

Figure 8. Community Desires in Tirtomulyo Village Land Management Source: Processed by the author 
Figure 8 . The crosstab analysis above shows that there are three indicators of community desire in Tirtomulyo Village. According to the Head of the Tirtomulyo Village Administration Section and the Implementer of Land Consolidation at the Regional Office of the National Land Agency for the Special Region of Yogyakarta, the people of Tirtomulyo Village want social facilities and public facilities (road access). There is a physical arrangement of land parcels so that each existing plot of land must have proper road access both from the width of the road and the physical road / there is hardening. Then the land consolidation certificate (assets legalization) can be continued development, community empowerment (access reform) around by paying attention to the directions in the local legislation and the installation of land parcel boundaries.

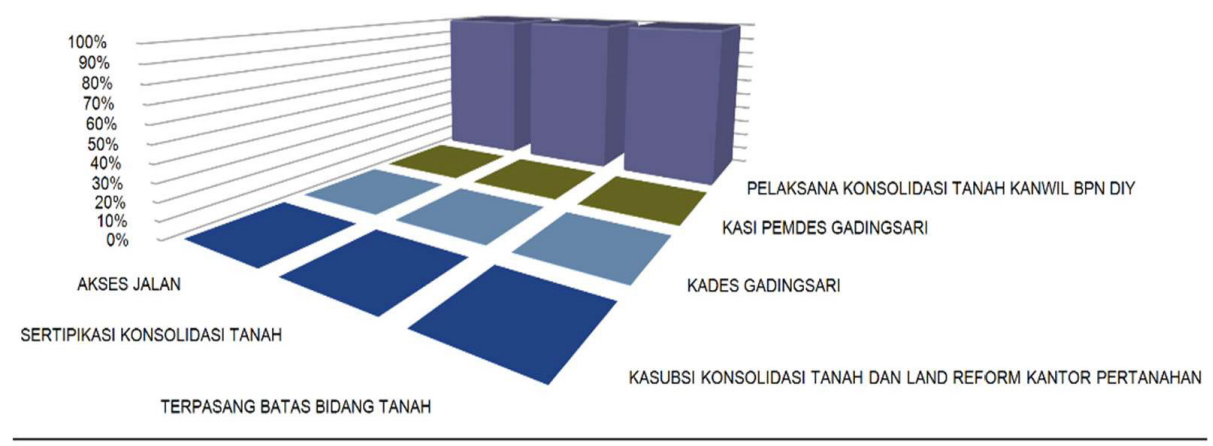

Figure 9. Community Desire in Land Management in Gadingsari Village Source: Processed by the author

According to what was conveyed by the Implementer of Land Consolidation at the DIY National Land Agency, the people of Gadingsari Village hope that after the land consolidation certification process (assets legalization) can be continued development, community empowerment (access reform) around by paying attention to the directions in local laws and regulations. Through the land consolidation certificate in Gadingsari Village, the community received education about the importance of adequate access to each plot of land. Community participation in the form of participation at every stage of land consolidation, in the provision of STUPs, in the establishment of road bodies and post-consolidation activities, and want adequate road access. 
Community Participation in Land Management in Tirtomulyo Village and Gadingsari Village, Sanden District, Bantul Regency

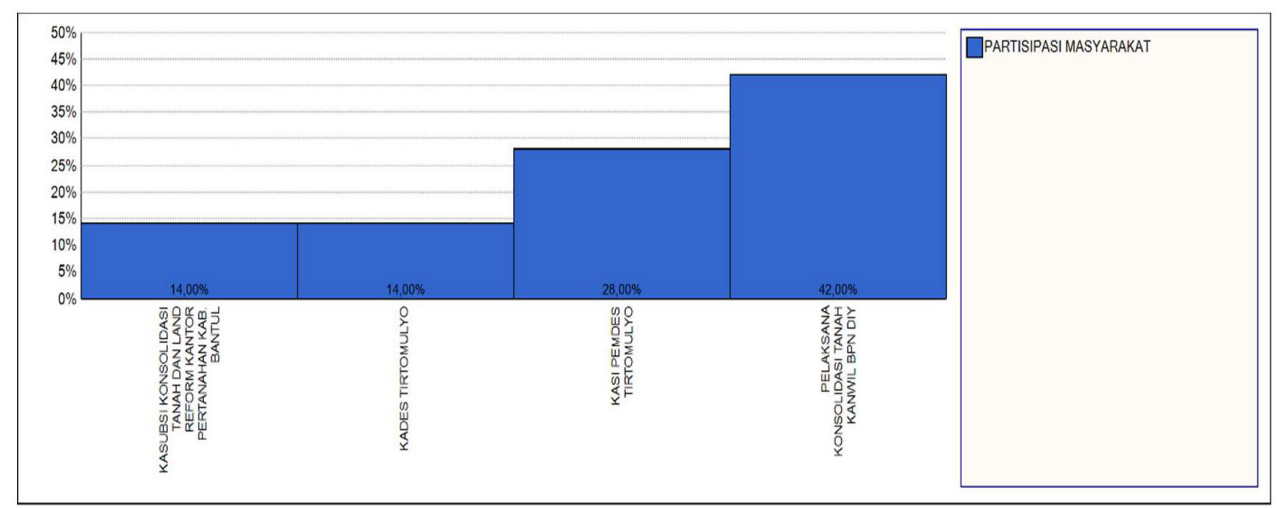

Figure 10. Community Participation in Tirtomulyo Village Land Management Source: Processed by the author

Figure 10. Above shows that the community participates in land management in Tirtomulyo Village. According to the Implementer of Land Consolidation at the DIY Regional Office, the community participates in land arrangement with a total frequency of $42 \%$. Was followed by the Head of the Village Administration Section at $28 \%$, then the Tirtomulyo Village Head at $14 \%$, and the Head of the Land Consolidation and Land Reform Subsection for the Bantul Regency Land Office by $14 \%$. The community participates in cooperation in realizing road sections, which in this case have become a program of the government in the same year. The community also participates in the land consolidation stage, the provision of Land Contribution for Development (STUP), the establishment of road bodies. And participate in Supervision, Monitoring and Coordination meetings which are held regularly by the Coordination Team.

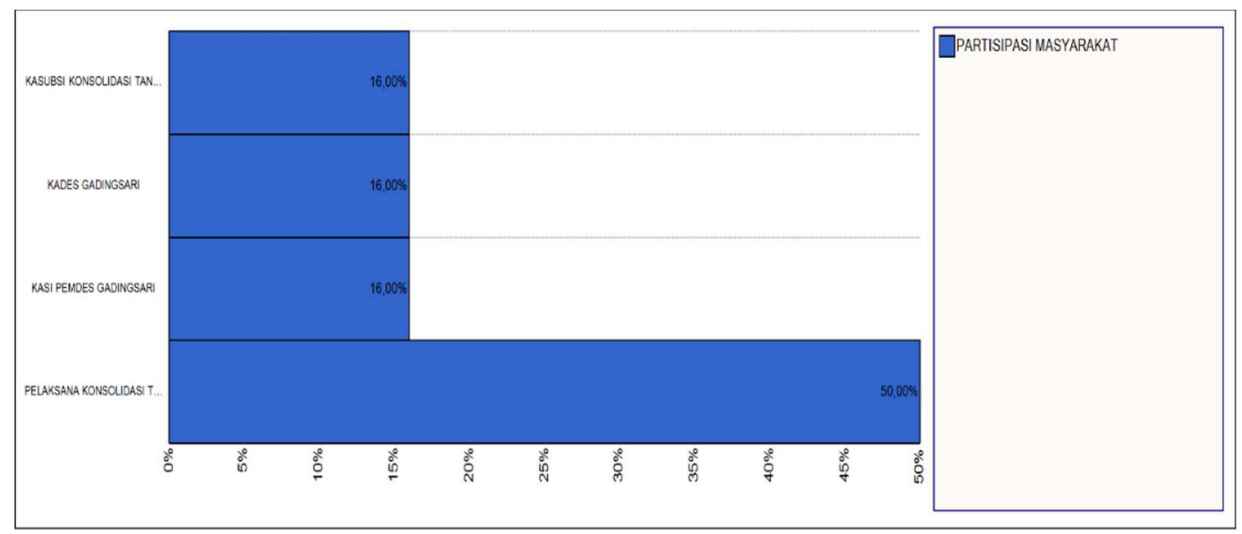

Figure 11. Community Participation in Land Arrangement in Gadingsari Village Source: Processed by the author 
The image above shows that the community supports the existence of land consolidation. This is because the Land Consolidation Certification Activity in Gadingsari Village is unique. After all, this location is an area that has been carried out by Land Consolidation Activities on an ongoing basis since 2009. The 2015 Land Consolidation Certification Activity is the fifth Land Consolidation Certificate.

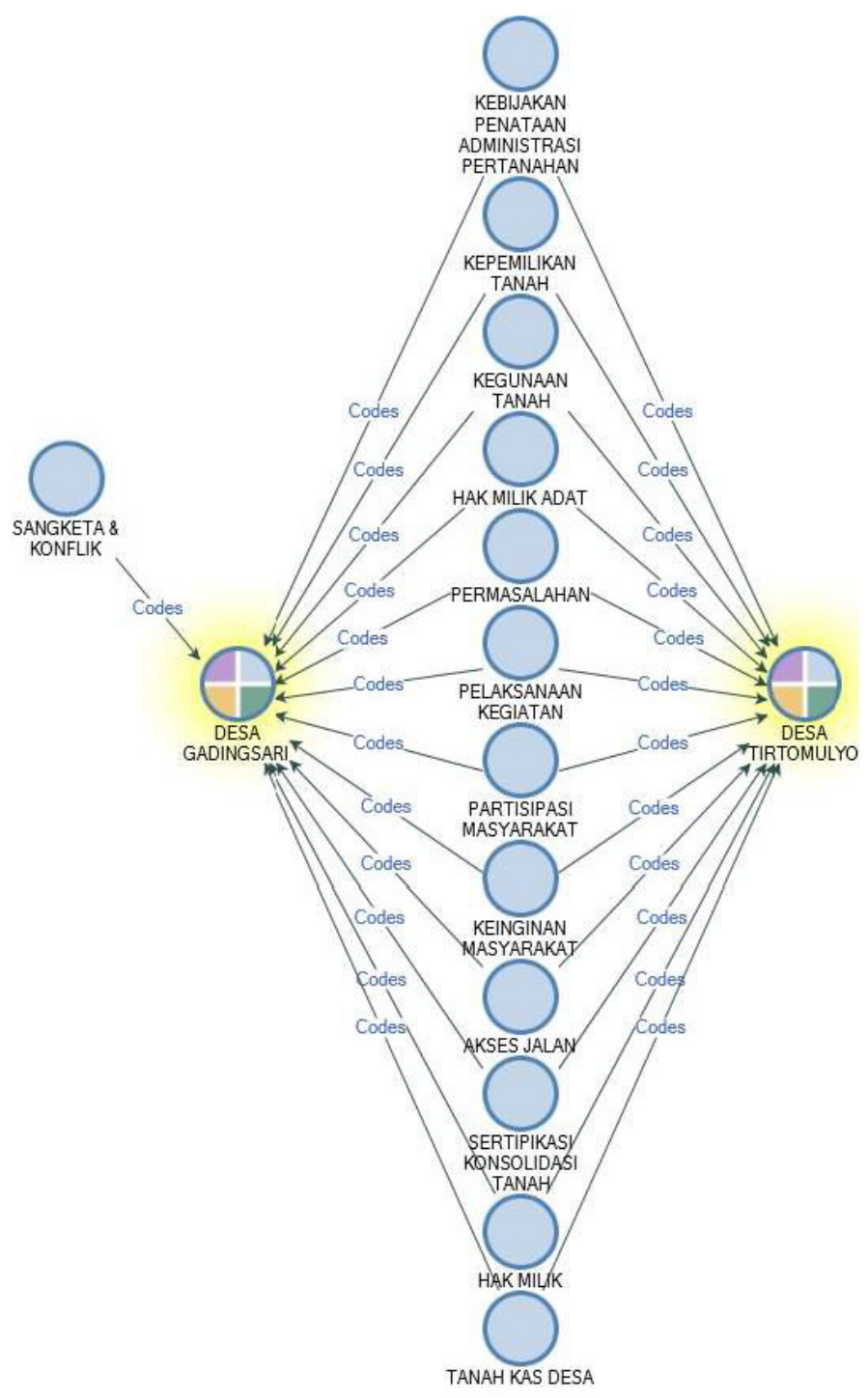

Figure 12. Interrelated Variables and Indicators in Tirtomulyo Village, Kretek District and Gadingsari Village, Sanden District, Bantul Regency Source: Processed by the author 
Based on Figure 12 above, it shows that between Tirtomulyo Village, Kretek District and Gadingsari Village, Sanden District, Bantul Regency, has several indicators with similarities in land management. The indicators referred to are land administration policy, land ownership, land use, customary ownership rights, problems in land management, activity implementation, community participation, community desires, road access, land consolidation certification, and village treasury land. What makes a difference is an indicator that has the potential for conflict, this indicator is found in Gadingsari Village, Sanden District, Bantul Regency.

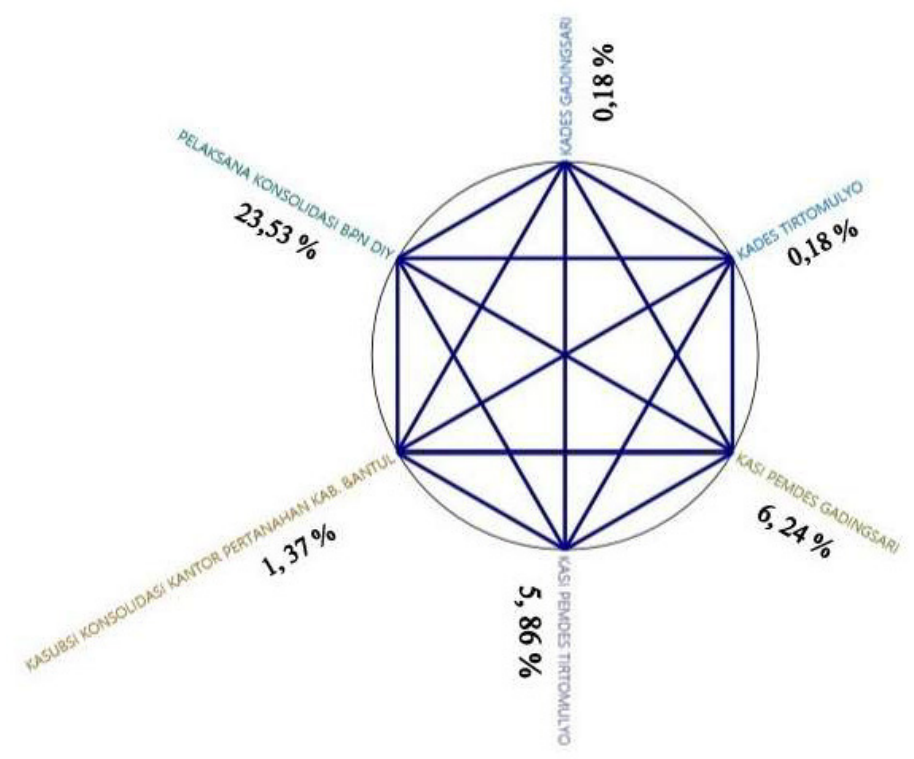

Figure 13. Correlation of Variables and Indicators Source: Processed by the author

Based on Figure 13 above shows that the frequency of correlation to variables and indicators in Tirtomulyo and Gadingsari Villages. The frequency of variables and indicators that have been submitted by the Implementer of Land Consolidation at the Regional Office of the DIY National Land Agency was 23.53\%, followed by the Head of the Gadingsari Village Government Section at $6.24 \%$, then followed by the Head of the Tirtomulyo Village Government Section at 5.86 \%, then the Head of Sub-Section for Consolidation of the Land Office of Bantul Regency at 1.37\%, and the Head of Tirtomulyo Village and the Village Head of Gadingsari each at $0.18 \%$. 
Land Arrangement Policy in Kepuharjo Village and Umbulharjo Village, Cangkringan District, Sleman Regency

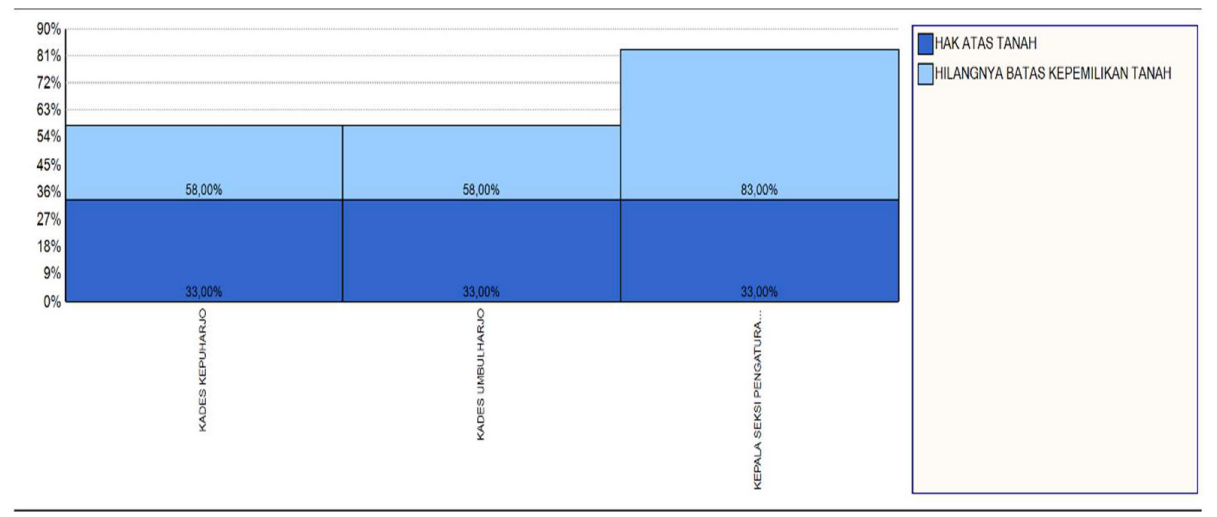

Figure 14. Land Ownership in Kepuharjo and Umbulharjo Villages Source: Processed by the author

Based on Figure 14 above, there are two similar land ownership indicators, namely land rights and loss of land ownership boundaries. According to what was conveyed by the Head of Kepuharjo Village, the Head of Umbulharjo Village, and the Head of the Section for Land Arrangement in Sleman Regency, the people who own land as the subject of land rights are provided with temporary shelters determined by the local government of Sleman Regency, and the eruption of the Merapi volcano that occurred last month. November 2010 destroyed the slopes of Merapi; this condition caused the loss of land ownership boundaries. The occurrence of a shift in water flow or river flow due to volcanic material covering large and small rivers and covering land ownership areas.

With the accumulation of land parcels by volcanic material due to the eruption of Mount Merapi, there are many signs of missing land parcels, this will have a great potential to lead to land disputes and conflicts and also many land parcels in the area whose road access is not optimal under these conditions, it is a necessary Land arrangement to restore the boundary markings of land parcels and optimization of road access with Land Consolidation. 


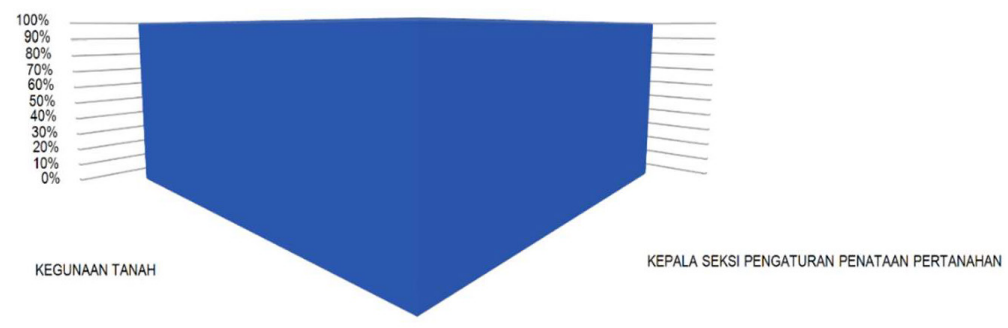

Figure 15. Land Use in Kepuharjo and Umbulharjo Villages Source: Processed by the author

Based on the Crosstab results above, it shows that the use of land in Kepuharjo Village is based on the Head of the Sleman Regency Land Arrangement Section. Land plots in Palemsari Hamlet after the eruption of Mount Merapi became a black area, burnt. This area has been transformed into a volcano tourism area, with a relatively dense monthly domestic and international tourists. Whereas in Pangukrejo Hamlet, land parcels' use after the eruption of Mount Merapi becomes barren land. This area is a place for domestic and international tourists to visit to enjoy nature's beauty on the slopes of Merapi. Furthermore, the use of land plots in Kaliadem Hamlet after Mount Merapi's eruption has become the Kaliadem Merapi Bunker, which is often also visited by domestic and foreign tourists.

Land Management Problems in Kepuharjo Village and Umbulharjo Village, Cangkringan District, Sleman Regency

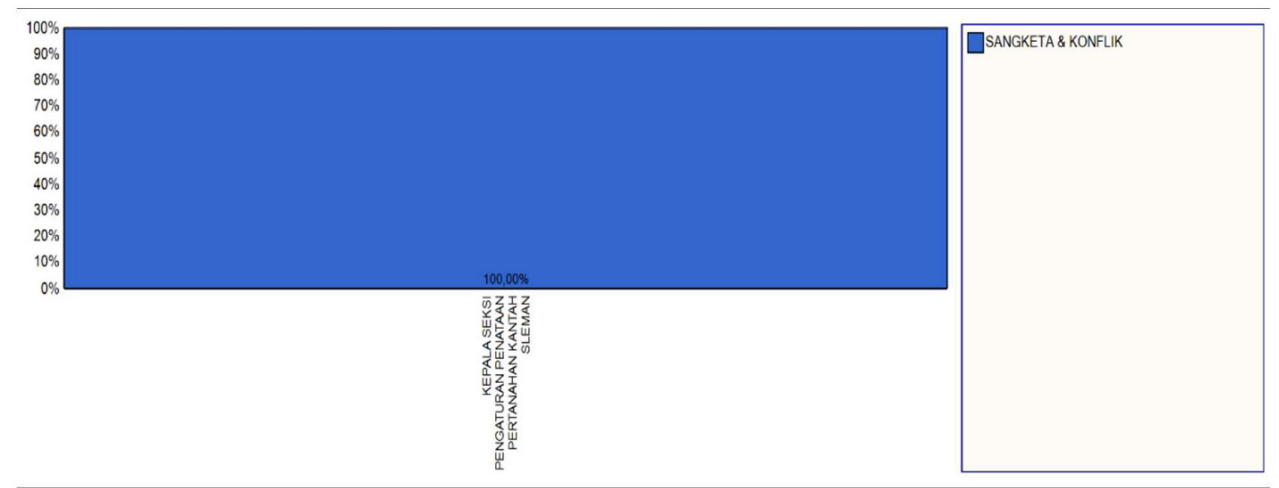

Figure 16. Problems in Kepuharjo and Umbulharjo Villages

Source: Processed by the author 
Based on the results above, it shows that there are problems in Kepuharjo Village and Umbulharjo Village, such as the accumulation of land parcels by volcanic material due to the eruption of Mount Merapi, so there are many signs of missing land parcels, this will have great potential to cause land disputes and conflicts as well as many land parcels in In those areas whose road access is not optimal under these conditions, it is necessary to make land arrangements to restore the land parcel boundary markers and optimize road access with land consolidation.

The Desire of the Community in Kepuharjo Village and Umbulharjo Village, Cangkringan District, Sleman Regency

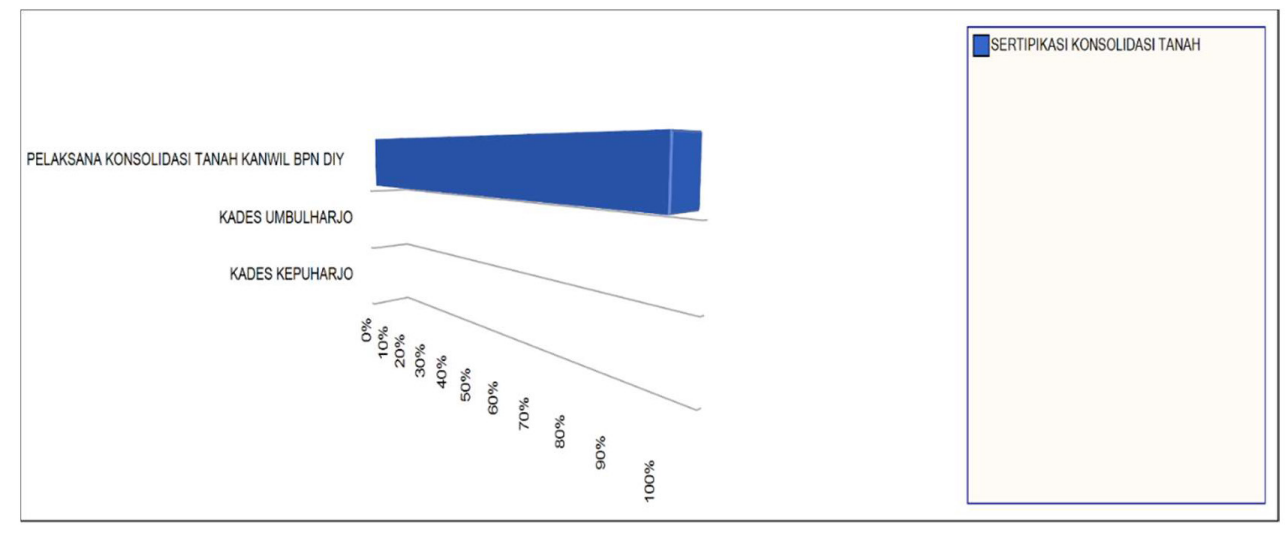

Figure 17. Problems in Kepuharjo and Umbulharjo Villages

Source: Processed by the author

Based on Figure 17. The crosstab analysis above shows that the wishes of the people of Kepuharjo and Umbulharjo villages want land consolidation certificates. As stated $100 \%$ by the Implementer of Land Consolidation at the DIY National Land Agency, it is hoped that after the process of land consolidation certification (assets legalization) it can be continued development, community empowerment (access reform) around by paying attention to the directions in local laws and regulations.

The Land Consolidation Certification Program in Cangkringan District is beneficial for communities in disaster-prone areas. It is expected to become a post-disaster management model in the land sector integrated with the implementation of development in the Special Region of Yogyakarta. 
Government Response to Land Management in Kepuharjo Village and Umbulharjo Village, Cangkringan District, Sleman Regency

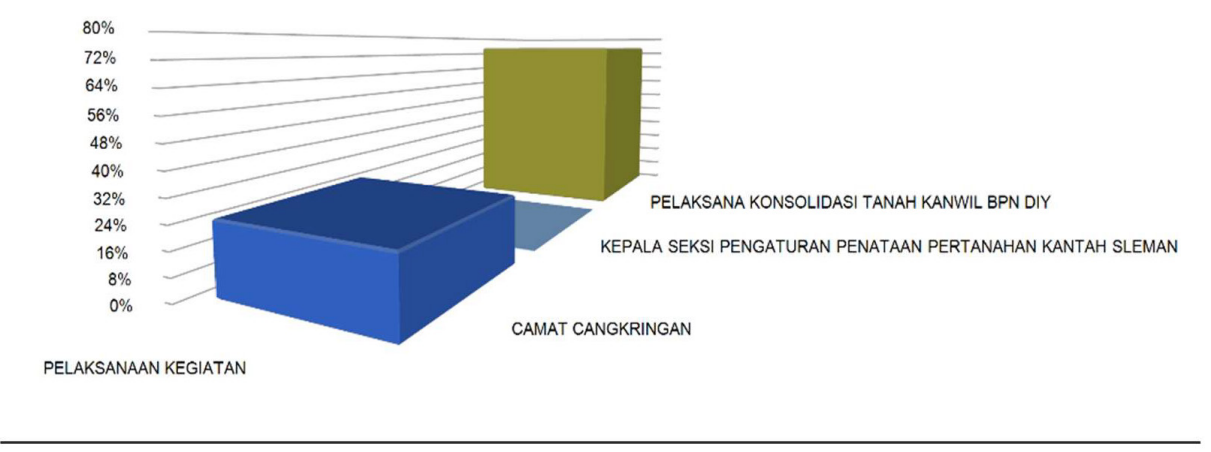

Figure 18. Government Response to Kepuharjo Village and Umbulharjo Village Source: Processed by the author

Based on Figure 18. above, it shows that the government is very supportive, this is manifested in their active participation in Supervision, Monitoring and Coordination meetings which are carried out regularly by the Coordination Team and the donation of tree seeds from the Plantation Service at the time of handing over the Land Certificate to the Community by the Minister of Agrarian Affairs, the Head of the National Land Agency who was accompanied by the Governor of Yogyakarta, Sri Sultan Hamengku Buwono X. 


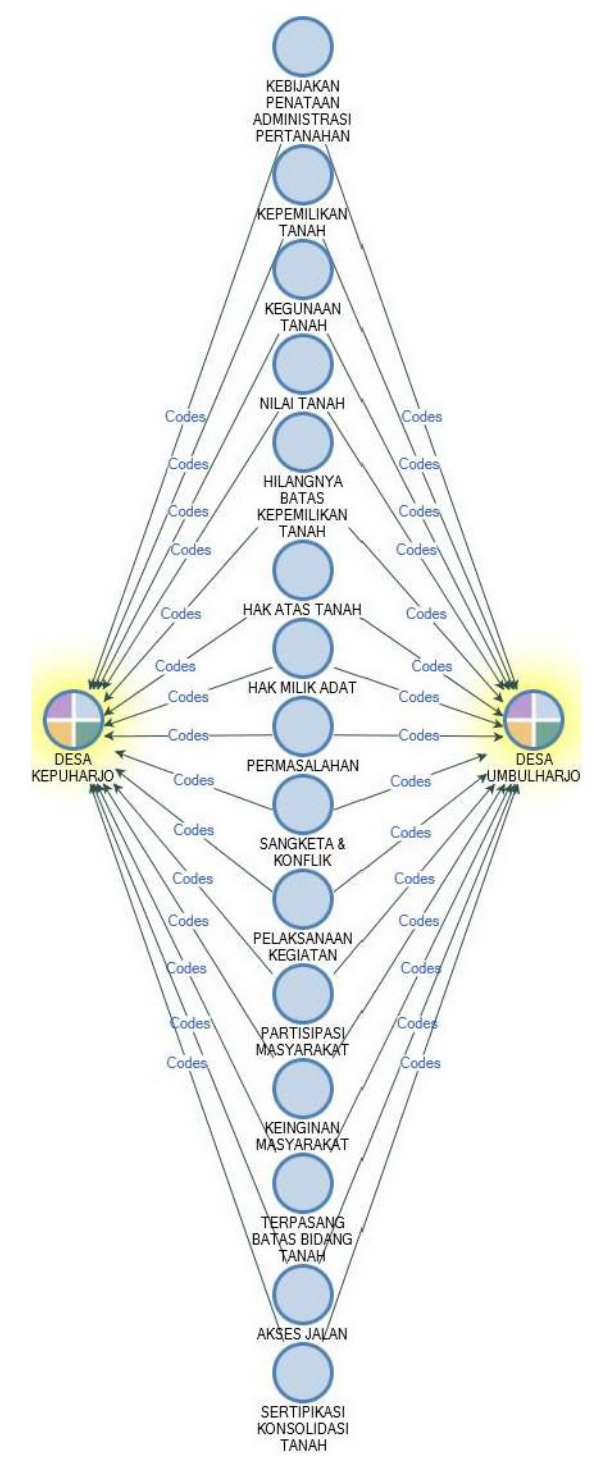

Figure 19. Interrelated Variables and Indicators in Kepuharjo and Umbulharjo Villages, Cangkringan District, Sleman Regency

Source: Processed by the author

Based on Figure 19. above shows that between Kepuharjo Village and Umbulharjo Village, Cangkringan District, Sleman Regency has several indicators of land management similarities. The indicators referred to are land administration policy, land ownership, land use, land value, loss of land ownership boundaries, land rights, customary ownership rights, problems in land management, and conflict, implementation of activities, community participation, community wishes, installed land parcel boundaries, road access, land consolidation certificate. In the variables and indicators obtained, there was no difference between Kepuharjo and Umbulharjo Villages. 


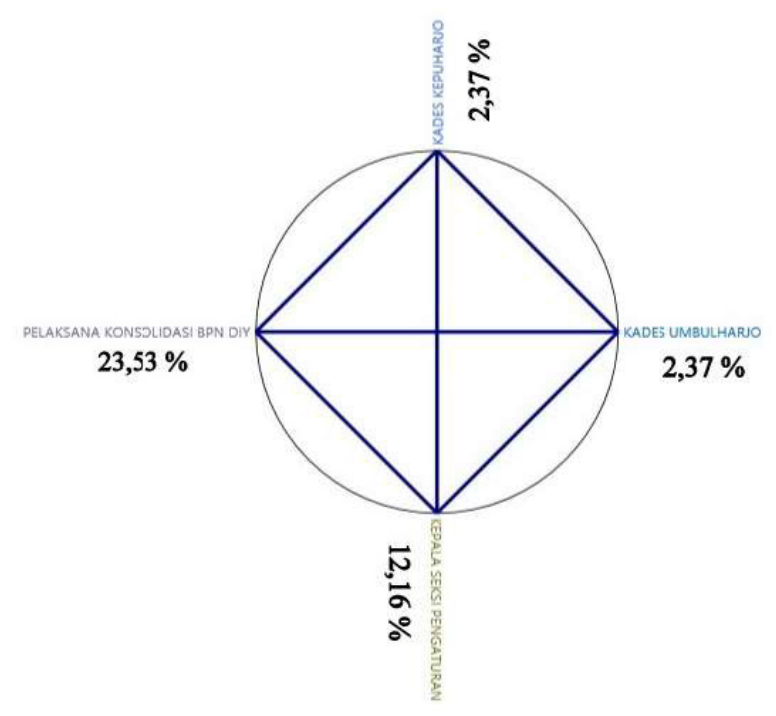

Figure 20. Correlation of Variables and Indicators

Source: Processed by the author

Figure 20 above shows the frequency of correlation to variables and indicators in Kepuharjo and Umbulharjo villages. The frequency of variables and indicators that have been submitted by the Implementer of Land Consolidation at the Regional Office of the DIY National Land Agency was 23.53\%, followed by the Head of the Land Arrangement Section for the Land Office of Sleman Regency at $12.16 \%$, followed by the Head of Kepuharjo Village and the Head Umbulharjo Village with $2.37 \%$ each. 
Comparison of Land Management Policies in Bantul Regency and Sleman Regency, Yogyakarta Special Region

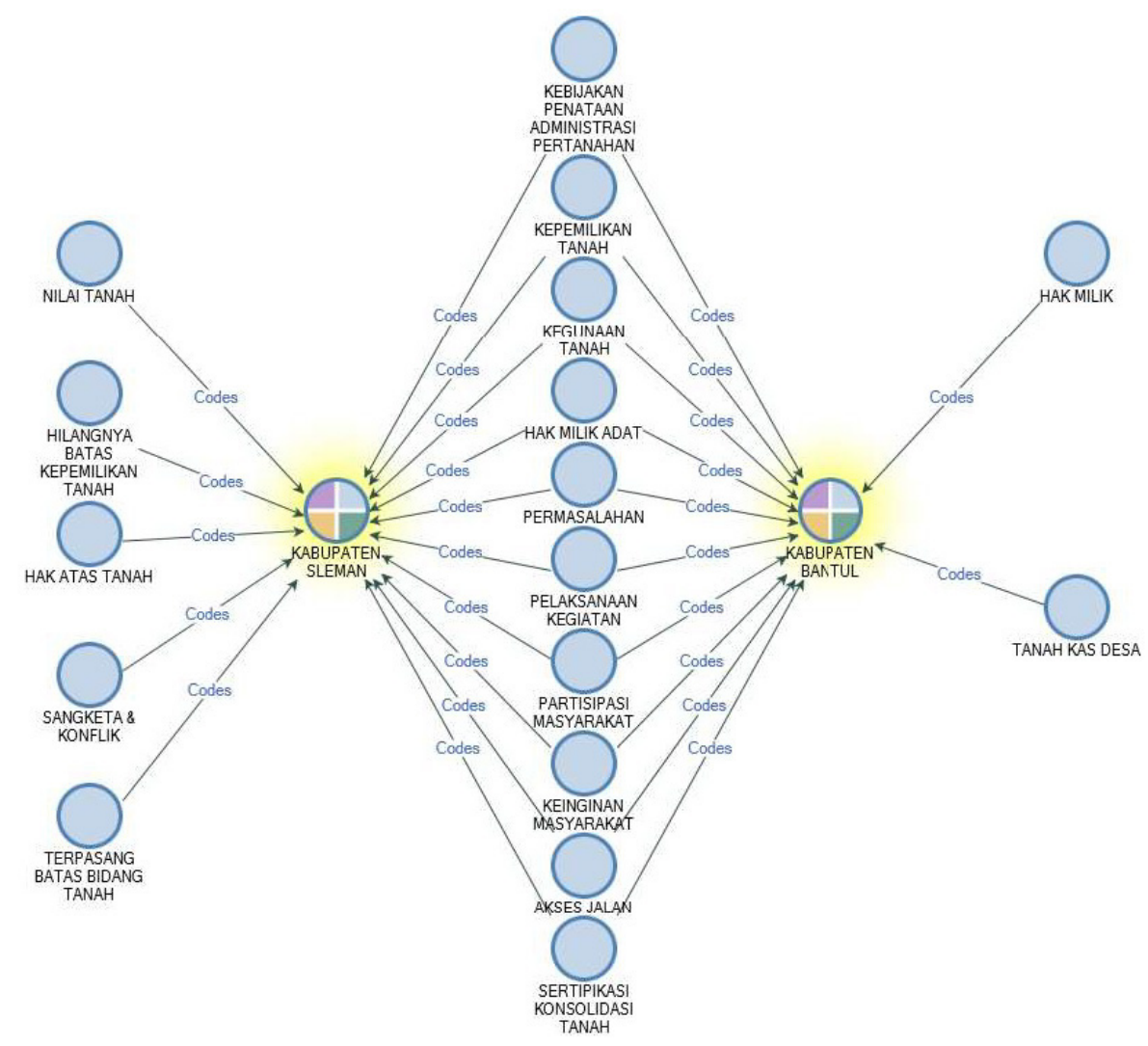

Figure 21. Comparison between Variables and Indicators in Bantul Regency and Sleman Regency, Yogyakarta Special Province Source: Processed by the author

Based on Figure 21. The comparative analysis above shows that the comparison shown by Bantul Regency and Sleman Regency. According to the variables and indicators obtained from each of the districts above, it can be seen that several variables and indicators correlate are interrelated. In the land administration structuring policy program, some indicators correlate land ownership, land use, customary property rights, problems in land management, activity implementation, community participation in the program, community desires, road access, and land consolidation certification. The differences were found in the land administration structuring policy program in Bantul and Sleman districts. From the different indicators obtained, Bantul Regency has indicators: Village treasury land and property rights. Simultaneously, the indicators obtained in Sleman Regency are land value, loss of land ownership boundaries, land rights, conflict, and land parcel boundaries. 


\section{CONCLUSION}

Based on the research above, it can be concluded that the land management policies in Tirtomulyo and Gadingsari Villages, in general, inland management use a land-use management pattern that includes control, use, and land use. Land ownership in Tirtomulyo Village is based on the 3 most prominent indicators: 80 percent of village treasury land, 71 percent of ownership rights, and customary property rights. Whereas in Gadingsari Village, based on the 3 most prominent indicators, namely property rights and customary property rights by 62 percent, however, village treasury lands amounted to 57 percent. In the aspect of land use in Tirtomulyo Village, 71 percent, land use is dominated by rice fields and settlements. While the land use in Gadingsari Village is 55 percent, the land use is dominated by gardens and rice fields. However, it cannot be separated from several problems in each village. In Tirtomulyo Village itself, there are land parcels that do not have road access, land parcels that occupy people's land, and inadequate road access. In Gadingsari Village itself, there are problems such as there are still parcels of land that do not have road access, inadequate road access, potential land conflicts, and can hamper economic growth in that location.

The lost land ownership boundaries dominate land ownership in Kepuharjo and Umbulharjo Villages; this is due to the impact of the eruption of Mount Merapi, which destroyed the slopes of Merapi. Meanwhile, in the aspect of land use, the area has become an international and domestic tourist spot. As for the problems that occur in Kepuharjo and Umbulharjo villages such as sangketa and land conflicts, the trigger for this is because there are many missing land parcel boundary marks, from land conflicts that can have an impact on sluggish economic growth, it is necessary to arrange land to restore the field boundary marks. Land and road access optimization with land consolidation.

\section{REFERENCES}

Alemie, B. K., Bennett, R. M., \& Zevenbergen, J. (2015). A socio-spatial methodology for evaluating urban land governance: the case of informal settlements. Journal of Spatial Science, 60(2), 289-309. https://doi.org/10.1080/14498596.2015.1004654

Arnowo, H., \& Handayani, D. T. (2016). Kebijakan Pertanahan pada Era Masyarakat Ekonomi Asean (MEA). BHUMI: Jurnal Agraria Dan Pertanahan, 2(2), 227. https:// doi.org/10.31292/jb.v2i2.73

Augustinus, C. (2010). Social Tenure Domain Model: What It Can Mean for the Land Industry and for the Poor. April, 11-16. http://citeseerx.ist.psu.edu/viewdoc/ download?doi=10.1.1.632.1855\&rep=rep1\&type=pdf

Blake, C. (2015). The Application of Geospatial Information - Land Administration and Management. July, 1-28. http://ggim.un.org/meetings/GGIM-committee/documents/ GGIM5/land admin and mngnt background paper 3.2 final.pdf 
Boone, C. (2015). Land tenure regimes and state structure in rural Africa: Implications for forms of resistance to large-scale land acquisitions by outsiders. Journal of Contemporary African Studies, 33(2), 171-190. https://doi.org/10.1080/ 02589001.2015.1065576

Byd $^{3}$ osz, J. (2015). The application of the Land Administration Domain Model in building a country profile for the Polish cadastre. Land Use Policy, 49, 598-605. https:/ / doi.org/ 10.1016/j.landusepol.2015.02.011

Chayani, D. A., \& Yuliani, F. (2013). IMPLEMENTASI KEBIJAKAN PERTANAHAN (STUDI KASUS PADA BAGIAN PENDAFTARAN TANAH di KECAMATAN TAMPAN KOTA PEKENBARU). Journal of Chemical Information and Modeling, 53(9), 1689-1699. https:// doi.org/10.1017/CBO9781107415324.004

Davison, J., \& Osuch, D. (2009). Land Administration Systems. Critical Issues in Systems Theory and Practice, February, 541-544. https://doi.org/10.1007/978-1-4757-9883-8_82

Dawidowicz, A., Radzewicz, A., \& Renigier-Biºzor, M. (2014). Algorithm for purposes of determining real estate markets efficiency with help of land administration system. Survey Review, 46(336), 189-204. https:// doi.org/10.1179/1752270613Y.0000000080

Dawidowicz, Agnieszka, \& • róbek, R. (2017). Land Administration System for Sustainable Development - Case Study of Poland. Real Estate Management and Valuation, 25(1), 112-122. https:// doi.org/10.1515/remav-2017-0008

Grover, R., Törhönen, M. P., Palmer, D., \& Munro-Faure, P. (2007). Good governance in land administration and land tenure. In Land Reform, Land Settlement and Cooperatives (Issue 2). http://www.cawater-info.net/bk/land_law/files/a1179e00.pdf

Hilhorst, T. (2008). Local governance institutions for sustainable natural resource management in Mali, Burkina Faso and Niger. 1-31. http://www.kit.nl/ smartsite.shtml?id=SINGLEPUBLICATION\&ItemID=2503

Kuma, S. S. (2018). Land Policy and Land Delivery System in Nigeria. Emerging Issues in Urban Land Use and Development, December 2017, 1-24. https:// www.researchgate.net/publication/322030158_Land Policy and Land Delivery System in Nigeria

Manzhynski, S., Siniak, N., • robek-Rózañska, A., \& • róbek, S. (2016). Sustainability performance in the Baltic Sea Region. Land Use Policy, 57, 489-498. https://doi.org/ 10.1016/j.landusepol.2016.06.003

Marsella. (2015). PERSPEKTIF PENANGANAN SENGKETA PERTANAHAN DI BADAN PERTANAHAN NASIONAL. Journal of Chemical Information and Modeling, 53(9), 16891699. https:// doi.org/10.1017/CBO9781107415324.004

Maynard, L., \& Jacobson, S. K. (2017). Stakeholder Participation in Wildlife Management: Adapting the Nominal Group Technique in Developing Countries for Participants with Low Literacy. Human Dimensions of Wildlife, 22(1), 71-82. https://doi.org/ $10.1080 / 10871209.2016 .1225139$ 
Nugroho, W. (2015). REORIENTASI KEBIJAKAN PEMERINTAH DAERAH DALAM PENERAPAN OTONOMI DAERAH DI BIDANG PERTANAHAN DAN PENATAAN RUANG (THE REORIENTATION OF LOCAL GOVERNMENT POLICY ON IMPLEMENTATION OF THE REGIONAL AUTONOMY IN THE FIELD OF LAND AND LAND USE). 1-19.

Puri, W. H. (2013). KONTEKSTUALITAS AFFIRMATIVE ACTION DALAM KEBIJAKAN PERTANAHAN DI YOGYAKARTA. http://jurnalbhumi.stpn.ac.id/index.php/JB/ article/download/157/143.

Sugiyono. (2018). Metode Penelitian Kualitatif: Untuk penelitian yang bersifat eksploratif, enterpretif, interaktif dan konstruktif (S. Y. Suryandari (ed.); Edisi ke-3). ALFABETA.

Van Doeveren, V. (2011). Rethinking Good Governance: Identifying Common Principles. Public Integrity, 13(4), 301-318. https:// doi.org/10.2753/PIN1099-9922130401

Zevenbergen, J., Vries, W. De, \& Bennett, R. (2016). Advances in responsible land administration. In Journal of Spatial Science (Vol. 61, Issue 1). https:/ / doi.org/10.1080/ 14498596.2016.1145619 